\title{
Height Control in Pot-grown 'Wood Violet' Gladiolus Using Ancymidol
}

\author{
P.M. Shaw, K.A. Schekel, and V.I. Lohr \\ Department of Horticulture and Landscape Architecture, Washington \\ State University, Pullman, WA 99164-6414
}

Additional index index words. A-Rest, gladioli, Gladiolus $\times$ hortulanus

Gladiolus $\times$ hortulanus Bailey currently is not grown as a potted plant, possibly because it is too tall. Most cultivars of Gladiolus are grown for cut flowers or for home gardens, where tall plants with large flowers are desirable. Production of potted Gladiolus, using growth retardants to achieve an acceptable size, could lead to the introduction of Gladiolus as a potted plant. Shaw et al. (1990) showed that a potted, 61-cm-high, 'Wood Violet' gladiolus had a favorable consumer response.

Gianfagna and Wulster (1986) showed ß[(4-chlorophenyl)methyl]- $a$-(1,1-dimethylethyl)-1 $H$-1,2,4-triazole-1-ethanol (paclobutrazol) and $a$-cyclopropyl- $a$-(4-methoxyphenyl)5-pyrimidinemethanol (ancymidol) to be effective in controlling the height of pot-grown freesia. Paclobutrazol has been shown to reduce the height of pot-grown Gladiolus $\times$ gandavensis 'Hunting Song' and 'Spic \& Span' (Hwang et al., 1986). We investigated the effects of ancymidol on plant height and flowering of 'Wood Violet' gladiolus.

Commercial-sized corms $(3-6.5 \mathrm{~cm}$ in diameter; Davids and Royston, Gardenia, Calif.) were given a 5-min preplant dip at labeled amounts in a mixture of methyl-1(butylcarbonyl)-2-benzimidazole-carbamate (benomyl; $0.5 \mathrm{~g} \cdot$ liter $^{-1}$ ) and methyl $N^{\prime}, N^{\prime}$ dimethyl- $N$-[(methylcarbamoyl)oxy]-1-

Received for publication 30 Jan. 1991. H/LA paper no. 90-21. The cost of publishing this paper was defrayed in part by the payment of page charges. Under postal regulations, this paper therefore must be hereby marked advertisement solely to indicate this fact. thiooxamimidate (Vydate; $3.9 \mathrm{ml} \cdot$ liter $^{-1}$ ) before planting. Five corms were planted per 2-liter pot. The medium was a commercial mix containing 35\% Manitoba horticulturegrade peatmoss : 15\% Manitoba special coarse peat : $40 \%$ pumice : $10 \%$ washed sand (by volume) and $110 \mathrm{~g}$ fritted micronutrients $/ \mathrm{m}^{3}$. The initial $\mathrm{pH}$ of the medium was 6.1 . The plants were grown during Summer 1989 in greenhouses at Washington State Univ., Pullman. The light intensity was 310 to 360 $\mu \mathrm{mol} \cdot \mathrm{m}^{-2} \cdot \mathrm{s}^{-1}$ and 140 to $150 \mu \mathrm{mol} \cdot \mathrm{m}^{-2} \cdot \mathrm{s}^{-1}$ for sunny and cloudy days, respectively. The days and nights averaged 25 and $17 \mathrm{C}$, respectively. Plants were watered as needed mg N/liter (20N-8.7P-16.7K). Ancymidol at $0,0.75$, or $1.5 \mathrm{mg}$ a.i. per pot was applied as a drench, in $120 \mathrm{ml}$ of solution, when the plants were $\approx 10 \mathrm{~cm}$ tall. When the plants were $20 \mathrm{~cm}$ high, the pots were spaced at 10.5 pots $/ \mathrm{m}^{2}$. The pots were arranged in a completely randomized design with five replications. After all visible buds had developed, the following were determined: the with tap water and fertilized weekly with 100

heights of leaves and inflorescences and the number of shoots per pot, days to visible bud, days to open flowers, florets per inflorescence, and days to anthesis. Data were tested by analysis of variance and single-degree-of-freedom contrasts.

Plants treated with ancymidol were significantly shorter than the control plants (Table 1). There was a significant linear trend of decreasing plant and inflorescence height with increasing concentrations of ancymidol. There was no effect of ancymidol on the number of shoots emerging from the pot, which averaged 7.9. Ancymidol did not affect the number of days to open flowers, inflorescences, florets per inflorescence, or days to anthesis. These results are consistent with results reported by Gianfagna and Wulster (1985), showing no delay in flowering of freesias with applications of ancymidol. The pots of Gladiolus had an average of 3.4 inflorescences per pot, with an average of 8.6 florets per inflorescence. Thus, ancymidol can be used to reduce the height of pot-grown Gladiolus and may eliminate one barrier to their introduction as a potted plant.

\section{Literature Cited}

Gianfagna, T.J. and G.J. Wulster. 1986. Growth retardants as an aid to adapting freesia for pot culture. HortScience 21:263-264.

Hwang, E.G., F.K. Suh, and B.H. Kwack. 1986. The influence of paclobutrazol on the growth and flowering of potted gladiolus ( $G$. gandavensis). J. Korean Soc. Hort. Sci. 27:73-80.

Shaw, P.M., K. Schekel, and V. Lohr. 1990. Consumers like potted gladiolus. Greenhouse Grower 8(5):54, 56-57.

Table 1. Effect of ancymidol on growth of pot-grown 'Wood Violet' gladiolus.

\begin{tabular}{|c|c|c|c|c|c|}
\hline \multirow{2}{*}{$\begin{array}{l}\text { Ancymidol } \\
\text { concn } \\
\text { (mg/pot) }\end{array}$} & \multicolumn{2}{|c|}{$\mathrm{Ht}$ of leaves ${ }^{\mathrm{z}}$} & \multicolumn{2}{|c|}{ Ht of inflorescence ${ }^{z}$} & \multirow{2}{*}{$\begin{array}{c}\text { Days to } \\
\text { visible bud }\end{array}$} \\
\hline & $\mathrm{cm}$ & $\%$ of control & $\mathrm{cm}$ & $\%$ of control & \\
\hline 0.0 & 66 & & 74 & & 68 \\
\hline 0.75 & 52 & 79 & 55 & 74 & 70 \\
\hline 1.5 & 47 & 71 & 49 & 66 & 73 \\
\hline \multicolumn{6}{|l|}{ Significance } \\
\hline Control vs. others & **** & $* * *$ & $* * *$ & $* * *$ & NS \\
\hline Ancymidol linear & **** & $* * *$ & $* * *$ & $* * *$ & NS \\
\hline
\end{tabular}

${ }^{z}$ Height of leaves and inflorescences measured from the top of the soil to the top of the leaves or to the top of the inflorescences, respectively.

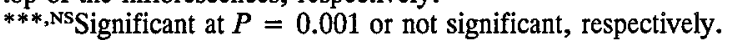

